\title{
Sıtmada Profilaksi ve Erken Tanı İçin Farkındalığın Önemi: Türkiye'de Yurt Dışı Kaynaklı iki Sıtma Olgusu
}

\author{
The Importance of Awareness for Malaria Regarding \\ Prophylaxis and Early Diagnosis: Two Imported Malaria \\ Cases in Turkey
}

\author{
Büşra Betül ÖZMEN ÇAPIN ${ }^{1}$, Meliha Çağla SÖNMEZER², Sema TORTOP', \\ Tuğçe ÜNALAN ${ }^{1}$, Hatice BÖLEK ${ }^{3}$, Sabri Engin ALTINTOP ${ }^{3}$, Ahmet Çağkan INKAYA ${ }^{2}$, \\ Gökhan METAN ${ }^{2}$, Sibel ERGÜVEN ${ }^{1}$ \\ ${ }^{1}$ Hacettepe Üniversitesi Tıp Fakültesi, Tıbbi Mikrobiyoloji Anabilim Dalı, Ankara. \\ ${ }^{1}$ Hacettepe University Faculty of Medicine, Department of Medical Microbiology, Ankara, Turkey. \\ ${ }^{2}$ Hacettepe Üniversitesi Tıp Fakültesi, Enfeksiyon Hastalıkları ve Klinik Mikrobiyoloji Anabilim Dalı, Ankara. \\ 2 Hacettepe University Faculty of Medicine, Department of Infectious Diseases and Clinical Microbiology, Ankara, Turkey. \\ ${ }^{3}$ Hacettepe Üniversitesi Tıp Fakültesi, İç Hastalıkları Anabilim Dalı, Ankara. \\ ${ }^{3}$ Hacettepe University Faculty of Medicine, Department of Internal Medicine, Ankara, Turkey.
}

Makale Atıfı: Özmen Çapın BB, Sönmezer MÇ, Tortop S, Ünalan T, Bölek H, Altıntop SE, Inkaya AÇ, Metan G, Ergüven S. Sıtmada profilaksi ve erken tanı için farkındalı̆ın önemi: Türkiye'de yurt dışı kaynaklı iki sıtma olgusu. Mikrobiyol Bul 2019;53(4):472-479.

\section{ÖZ}

Türkiye'de en sık görülen sıtma etkeni Plasmodium vivax olmakla beraber, son yıllarda yurt dışı kaynaklı sıtma olguları bildirilmektedir. Bu çalışmada, Sahra-altı Afrika kaynaklı iki sıtma olgusu sunulmuş, sıtmanın önlenmesinde profilaksinin öneminin vurgulanması ile tanı ve tedavi yaklaşımlarının tartışılması amaçlanmıştır. İlk olgu Gana Cumhuriyeti'nde çalışan 45 yaşında erkek hasta olup Türkiye'ye döndükten sonra ateş, terleme, titreme şikayetleriyle Hacettepe Üniversitesi Hastaneleri Erişkin Acil Servisine başvurmuştur. Genel durumu iyi olan ve fizik muayenesinde patolojik bulguya rastlanmayan hastanın hastanedeki ilk ateş epizodu sonrası tam kan sayımında anemi ve trombositopeni, biyokimyasal testlerinde ise hiponatremi ve alkalen fosfataz yüksekliği saptanmıştır. İkinci olgu, Fildişi Sahili'nden yaklaşık iki hafta önce dönen 39 yaşında erkek hasta olup ateş, terleme, titreme ve halsizlik şikayetleriyle hastanemiz acil servisine başvurmuştur. Hastanın yapılan fizik muayenesinde solunum seslerinde azalma ve splenomegali saptanmış, tam kan sayımında pansitopeni ve biyokimyasal testlerinde karaciğer enzimlerinde yükseklik tespit edilmiştir. Laboratuvarımızda hastalara ait kalın damla preparatının mikroskobik incelemesi sonucu taşlı yüzük hücreleri görülmesi, ince yayma preparatında ise aynı eritrosit içinde birden çok taşlı yüzük hücreli şeklin görülmesi ve olgun trofozoit veya şizont formlarının görülmemesi ile Plasmodium falciparum'a bağlı gelişen sıtma tanısı konulmuştur. Hızı antijen testi (Digamed, Belçika) ikinci hastada P.falciparum ve P.vivax için pozitif sonuç vermiş ve hasta şiddetli sıtma kliniğine bağlı olarak yoğun bakım ünitesinde takip edilmiştir. Her iki 
hasta da endemik bölgelere (Gana Cumhuriyeti ve Fildişi Sahili) sık ve uzun süren seyahatleri nedeniyle sıtma profilaksisi kullanmadıklarını belirtmişlerdir. Klorokin direnci yüksek bölgeye seyahat öyküleri olması nedeniyle, hastalara Dünya Sağlık Örgütü güncel önerilerine uygun doz ve sürede artemeter/lumefantrin tedavisi başlanmıştır. i̇kinci olguya olası P.vivax enfeksiyonuna yönelik primakin tedavisi eklenmiştir. Tedavi ile hastaların kliniği düzelmiş ve laboratuvar bulguları normale dönmüştür. Sonuç olarak, endemik bölgeye seyahat eden bireyler profilaksinin önemi hakkında bilgilendirilmeli, bireylere uygun profilaksi başlanmalı ve seyahat sonrası ateş ile kliniğe başvuran hastaların ayıııcı tanısında sıtma akılda bulundurulmalıdır.

Anahtar kelimeler: Plasmodium falciparum; sitma; artemeter; artesunat.

\section{ABSTRACT}

In spite of the fact that Plasmodium vivax is the leading causative agent of malaria in our country, imported malaria cases have been reported, recently. In this report, two malaria cases originated from sub-Saharan Africa, and their diagnostic and therapeutic approaches were aimed to be presented. First case, 45-year-old male, who has been working in Republic of Ghana, was admitted to Hacettepe University Hospitals Emergency Service with complaints of fever, sweating and shivering, after returning to Turkey. On admission, his general condition was fine and his physical examination revealed no pathological finding. After his admission, a fever episode occured and his blood tests revealed anemia, trombocytopenia and increased alkaline phosphatase level. Second case, 39-year-old-male admitted to the emergency service with the complaints of fever, shivering and myalgia. His physical examination revealed decreased breath sounds and splenomegaly, his laboratory tests resulted in pansitopenia and elevated liver enzymes. In the thick blood smears of the patients ring formed young trophozoites are detected and in the thin films multiple ring forms demonstrated in one erythrocyte with the absence of mature trophozoites and schizont forms, which were compatible with falciparum malaria. The rapid antigen test (Digamed, Belgium) of the second case found to be positive for both Plasmodium falciparum and P.vivax and this patient followed-up in intensive care unit due to his deterioration of general condition, respiratory distress, hematuria and change of consciousness. Neither cases were commenced on malaria prophylaxis. Both patients have been in countries which chloroquine resistance is commonly seen, they were treated with artemether/lumefantrine as current World Health Organization recommended. Targeting hypnozoites of P.vivax, primaquine was added to the therapy of the second patient. Both patients resulted in cure. In conclusion, while travelling to endemic countries, people should be informed about the importance of malaria prophylaxis and prophylaxis should be commenced immediately and continued appropriately. Additionally, malaria should always be considered in the differential diagnosis of high fever for the patients who admitted to the hospital with a travelling history to these countries.

Keywords: Plasmodium falciparum; malaria; artemether; artesunate.

\section{Giriş}

Sıtma, günümüzde önemini koruyan, morbidite ve mortaliteye neden olabilen bir protozoal hastalıktır. Ateş şikayeti ile kliniğe yapılan başvurularda hastanın seyahat öyküsü sorgulanmalı, özellikle endemik bölgeye gitme öyküsü bulunan hastada sıtma mutlaka araştırılmalıdır. Dünya Sağlık Örgütü (DSÖ)'nün 2018 yılında yayımladığı Dünya Sıtma Raporuna göre 2017 yılında 87 ülkeden 219 milyon sıtma olgusu bildirilmiş ve bu olguların 435.000'i ölümle sonuçlanmıştır. Olguların \%92'si Afrika kökenlidir. Gana ve Fildişi Sahili, birbirlerine sınır komşusu olan, Afrika'nın batısında bulunan, güneyde Atlas Okyanusu'na kıyısı olan Sahra-altı Afrika ülkeleridir. Sahra-altı Afrika ülkelerindeki sıtma olgularının \%99.7'sinden Plasmodium falciparum sorumludur ${ }^{1}$. Ülkemizde yerli bulaştan sorumlu tür Plasmodium vivax'tır. Ancak 2013 yılından itibaren nüks görülen olgular dışında yerli olgu bildirilmemiştir ${ }^{2}$. Bunun yanında diğer türlerle gelişen importe sıtma olguları bildirilmekte$\operatorname{dir}^{3-5}$. Günümüzde çeşitli nedenlerle seyahat eden kişi sayısı artmaktadır ve endemik böl- 
gelere yapılan seyahatlerde uygun profilaksi kullanılmaması durumunda hastalık gelişme riski ortaya çıkmaktadır. Bu çalışmada, Sahra-altı Afrika (Gana Cumhuriyeti ve Fildişi Sahili) kökenli iki sıtma olgusu sunulmuş, endemik bölgeye seyahat öncesi profilaksi uygulanmasının önemi vurgulanmış, tanı ve tedavi yaklaşımları tartışılmıştır.

\section{OLGU SUNUMLARI}

\section{Olgu 1}

Son altı ayı Gana'da olmak üzere toplam dört yıldır Afrika'da çalışan 45 yaşında Türk erkek hasta, Afrika'da bulunduğu sürece profilaksi kullanmadığını belirtmiştir. Ateşli hastalık öyküsü veya bilinen hastalığı olmayan hasta Türkiye'ye döndükten iki gün sonra ateş, terleme ve titreme şikayetleriyle hastanemiz acil servisine başvurdu. Başvuru sırasında ateşi $38.1^{\circ} \mathrm{C}$, tansiyonu $150 / 90 \mathrm{mmHg}$, nabzı 134/dakika olan hastanın fizik muayenesinde patolojik bulguya rastlanmadı. Tam kan sayımında hemoglobin $14.9 \mathrm{~g} / \mathrm{dl}$, lökosit sayısı

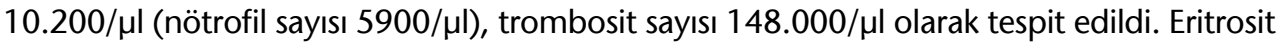
sedimentasyon hızı $22 \mathrm{~mm} / \mathrm{saat}$, alanin aminotransferaz (ALT) $57 \mathrm{U} / \mathrm{L}$, aspartat aminotransferaz (AST) $36 \mathrm{U} / \mathrm{L}$, alkalen fosfataz (ALP) $149 \mathrm{U} / \mathrm{L}$, gama-glutamil transferaz (GGT) 31 $\mathrm{U} / \mathrm{L}$, indirekt bilirubin $1.37 \mathrm{mg} / \mathrm{dl}$, kan üre azotu (BUN) $14.98 \mathrm{mg} / \mathrm{dl}$, kreatinin $0.88 \mathrm{mg} /$ dl, sodyum $127 \mathrm{mEq} / \mathrm{L}$ ve potasyum $4.25 \mathrm{mEq} / \mathrm{L}$ olarak saptandı. Postero-anterior akciğer grafisi ve abdomen ultrasonografik görüntülemesi normal olan hastanın takibinde ateşi $38.9^{\circ} \mathrm{C}^{\prime}$ ye kadar çıtı. Hastanedeki ilk ateş sonrası hemoglobin değeri $12.9 \mathrm{~g} / \mathrm{dl}$, trombosit sayısı ise 106.000/ $\mu l^{\prime}$ ye düştü. Parazitoloji Laboratuvarında değerlendirilen Giemsa boyalı preparatının mikroskobik incelemesinde eritrosit içinde birden çok genç trofozoit görülmesi, diğer evrim şekillerinin görülmemesi nedeniyle P.falciparum'a bağlı sıtma tanısı konuldu (Resim 1,2). Artemeter/lumefantrin tedavisi uygulanan hasta tedavi ile taburcu edildi.

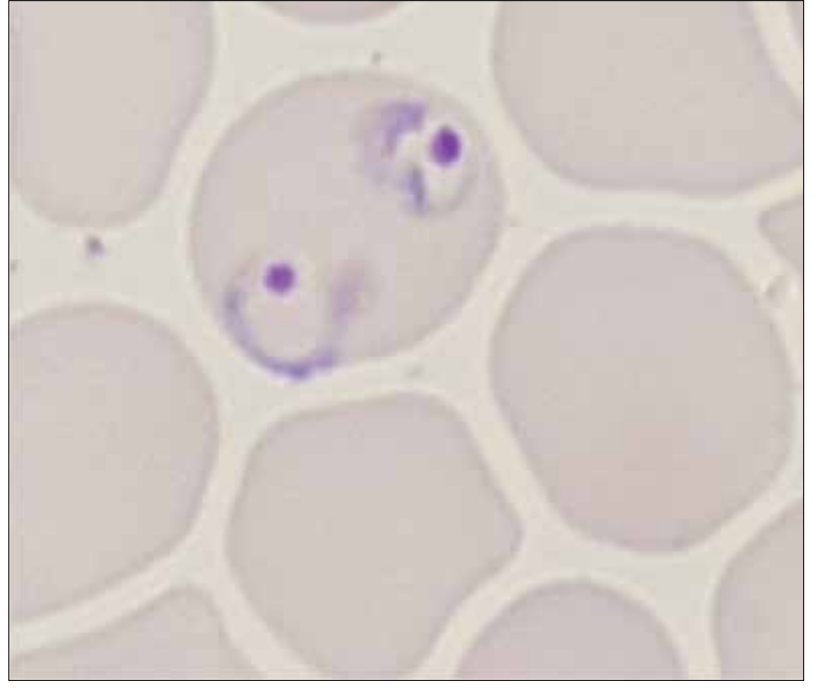

Resim 1. Olgu 1'e ait Giemsa boyalı ince yayma preparatında eritrosit içinde genç trofozoitler. 


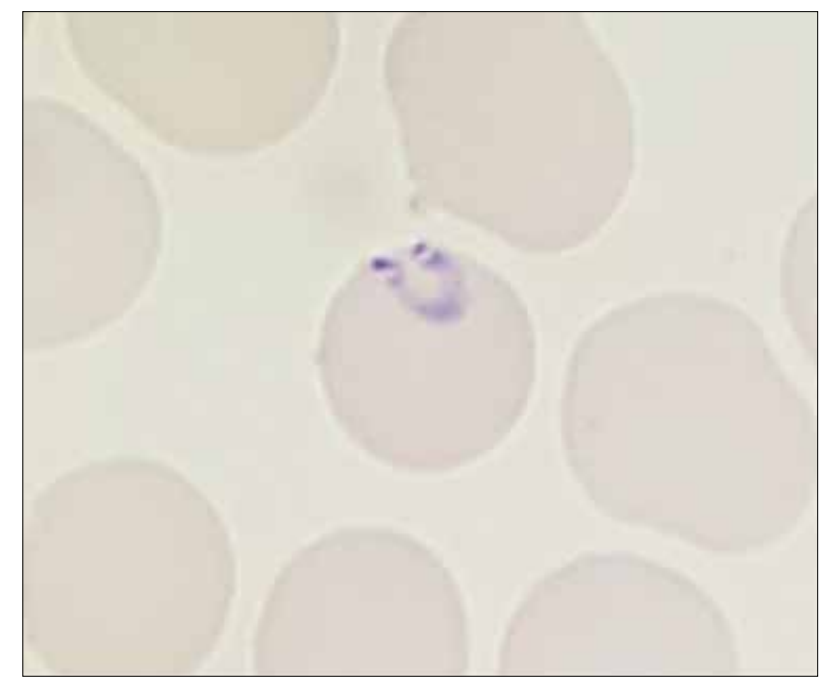

Resim 2. Olgu 1'e ait Giemsa boyalı ince yayma preparatında eritrosit içinde çift çekirdekli genç trofozoit.

\section{Olgu 2}

Fildişi Sahili'nden iki hafta önce dönen 39 yaşında erkek hasta, ateş ve titreme şikayetleriyle çeşitli kliniklere başvurmuş ve farklı enfeksiyon tanılarıyla antimikrobiyal tedaviler almıştır. Şikayetleri düzelmeyen hasta dış merkezde tespit edilen C-reaktif protein (CRP) yüksekliği ve trombositopenisi nedeniyle hastanemize yönlendirildi. Başvuru sırasında yapılan fizik muayenesinde, azalmış solunum sesleri ve splenomegali saptandı. Karaciğer enzimlerinde yükseklik saptanan (ALT, AST, ALP ve GGT değerleri sırasıyla; $57 \mathrm{U} / \mathrm{L}, 49 \mathrm{U} / \mathrm{L}$, $123 \mathrm{U} / \mathrm{L}$ ve $228 \mathrm{U} / \mathrm{L}$ ) ve tam kan sayımında eritrosit sayısı $4.04 \times 10^{6} / \mu \mathrm{l}$, lökosit sayısı 4.2 $\times 10^{3} / \mu$ l ve trombosit sayısı $13 \times 10^{3} / \mu$ l olarak tespit edildi. Hastanın hızlı antijen testinde (Digamed, Belçika) P.vivax ve P.falciparum pozitifliği saptandı. Laboratuvarımızda değerlendirilen ince yaymasında P.falciparum'u düşündüren bir eritrosit içinde birden çok taşlı yüzük şekli ve çift taşlı küçük yüzük şeklinde iki çekirdekli genç trofozoitler görülmüş, diğer evrim şekillerine rastlanmadı (Resim 3,4). Hasta şiddetli sıtma kliniğini düşündüren genel durum kötüleşmesi, oksijen ihtiyacı, hematüri ve kısa süreli bilinç değişikliği nedeniyle iç hastalıkları yoğun bakım ünitesinde takip edildi. Artemeter/lumefantrin başlanan hastanın, şiddetli sıtma kliniği nedeniyle tedavisine parenteral artesunat eklendi. Olası P.vivax enfeksiyonuna yönelik primakin eklendi. Takibinde parazitemi saptanmayan hasta tedavi ile taburcu edildi.

\section{TARTIŞMA}

Dünyada 2017 yılında 219 milyon sıtma olgusu ve 435 bin sıtmaya bağlı ölüm saptanmıştır ${ }^{1}$. Sıtmaya bağlı morbidite ve mortalite hala tehdit edici boyutlardadır. Günümüzde ülkemiz sıtmanın elimine edildiği ülkeler arasına girmiştir ${ }^{6}$. Türkiye'den 2010 ve $2011^{\prime}$ de yerli olgu bildirilmemiştir ${ }^{6,7}$. 2012'de 206 P.vivax olgusunu içeren bir salgın saptanmış- 


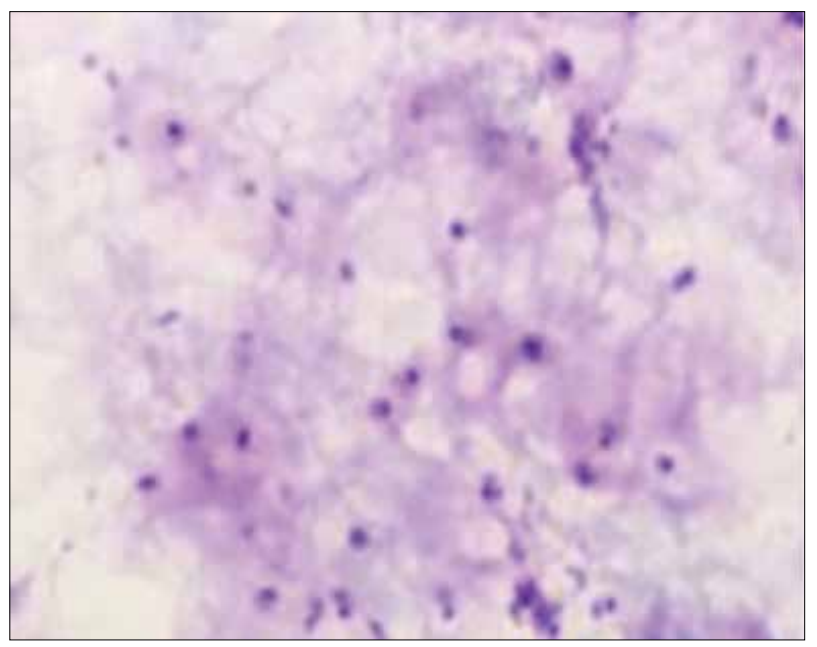

Resim 3. Olgu 2'ye ait Giemsa boyalı kalın damla preparatında görülen genç trofozoitler.

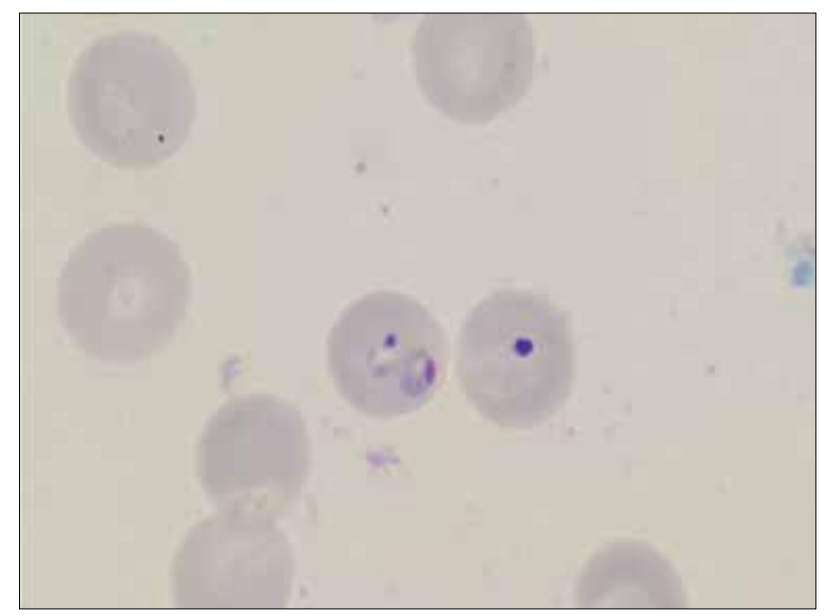

Resim 4. Olgu 2'ye ait Giemsa boyalı ince yayma preparatında eritrosit içinde görülen genç trofozoitler.

tır $^{8}$. 2013'den itibaren relaps olgular dışında yerli sıtma olgusu görülmemesine rağmen², yurt dışı kaynaklı sıtma olguları bildirilmektedir ${ }^{3,4,9-11}$. Sağmak Tartar ve Akbulut ${ }^{9}, 2011$ 2017 yılları arasında P.falciparum'un etken olduğu 15 olgu saptamışlardır ${ }^{9}$. Zorbozan ve arkadaşları ${ }^{10}$ sırasıyla P.vivax ve P.falciparum etken olmak üzere iki yurt dışı kaynaklı sıtma olgusu saptadıklarını belirtmişlerdir ${ }^{10}$. İnkaya ve arkadaşları ${ }^{4}$ ile Sümer ve arkadaşları ${ }^{11}$ P.falciparum'un etken olduğu yurt dışı kaynaklı sıtma olguları bildirmişlerdir ${ }^{4,11}$. Günümüzde nüfus hareketleri, gezi ve çalışma amaçıı seyahatlerin daha çok yapılması yurt dışı kaynaklı sıtma olguları için risk faktörleridir. Sıtma profilaksisi amacıyla endemik bölgeye 
seyahat öncesi süre, seyahat edilecek bölgedeki etkenin türü, bulunan türün direnç özelliği, bireyin kendi özellikleri (yaş, gebelik, glukoz-6-fosfat dehidrogenaz eksikliği varlığı gibi) ve ilaç uyumu göz önünde bulundurularak uygun profilaksi başlanmalıdır ${ }^{12}$.

İkinci olguda ilk ateş yükselmesinden tedavinin başlanmasına kadar yaklaşık iki hafta geçmiştir. Hastanın ateşi ilk kez Fildişi Sahili’nden Türkiye'ye döndükten sonra yükselmiş ve üst solunum yolu enfeksiyonuna yönelik antimikrobiyal tedavi almıştır. Şikayetlerinin devam etmesi nedeniyle Ankara'da bir sağlık kurumuna başvurmuş, ancak sıtmaya yönelik tanı testi yapılmamıştır. Hastada trombositopeni ve CRP yüksekliği saptanması nedeniyle hasta merkezimize yönlendirilmiştir. Ateş ile başvuran hastalarda ayrıntılı anamnez alınması çok önemlidir. Ayrıntılı anamnez ateşin karakterini (ölçüldüyse en yüksek değeri, ne kadar sürdüğü ve ne sıklıkta tekrar ettiği, eşlik eden semptomlar gibi), seyahat öyküsünü ve kan transfüzyonu yapılıp yapılmadığı bilgilerini içermelidir. Falciparum sıtmasında ateşin her zaman düzenli aralıklar halinde görülmeyeceği akılda tutulmalıdır. Endemik bölgeye seyahat öyküsü olması sıtma tanısına götüren ilk ipucu olabilir ve mutlaka sorgulanmalıdır. Sıtma için doğru ve tam profilaksi kullanımının da sıtma tanısını dışlamayacağı göz önünde bulundurulmalıdır.

DSÖ, tür düzeyinde tanımlaması yapılamayan durumlarda, komplike olmayan P.falciparum olgularında ve klorokin direnci olması halinde tedavide artemisinin kombinasyonu kullanımını önermektedir ${ }^{13}$. Şiddetli sıtma kliniği olması durumunda ise hasta oral tedaviye geçene kadar en az 24 saat parenteral artesunat tedavisi kullanılması gerektiği bildirilmiştir. P.vivax veya Plasmodium ovale etken ise nüksleri önlemek adına, primakin tedavisi verilmesi gerekmektedir ${ }^{13}$. Olguların klorokin dirençli P.falciparum'un endemik olduğu bölgeye seyahat öyküleri olması nedeniyle tedavide artemisininli kombinasyonlar kullanılmıştır. İkinci olguda ise şiddetli sıtma kliniği nedeniyle bu tedaviye ek olarak parenteral artesunat ve P.vivax'a yönelik primakin tedavisi de verilmiştir. Her iki olgu da tedavi ile taburcu edilmiştir. Etken olarak P.falciparum saptanan ağır sıtma olgularının tedavisinde, artemisinin türevi antimalaryallere ulaşmak zaman alacaksa hastaya intravenöz kinidin başlanabilir. Ancak bu durumda hastanın kliniği yakından takip edilmeli ve kardiyak monitörizasyonu sağlanmalıdır. Benzer durumda kinine ilave olarak oral doksisiklin de tercih edilebilir ${ }^{13}$.

Boyalı mikroskobik inceleme, gelişen tanı testlerine rağmen tanıda halen altın standart yöntem olarak kabul edilmektedir. Mikroskobik inceleme ucuz ve saha koşullarında kolay uygulanabilen bir yöntem olmasıyla birlikte özellikle tür düzeyinde tanı koymada deneyimli mikroskopist gerektirmektedir. Her iki olgunun tanısında da laboratuvarımıza gönderilen kalın damla ve ince yayma preparatlarında yalnızca genç trofozoitler görülmüştür. Ancak ikinci olguda yapılan hızlı antijen testinde P.falciparum ve P.vivax'a ait bant görülmüştür.

Hızı antijen testleri, kullanımlarının uzmanlık gerektirmemesi, oda sıcaklığında uzun süre stabil kalabilmesi, hızlı sonuçlanması nedeniyle tanıya yardımcı test olarak kullanılabilir. Kullanılan kitlerin duyarlılık ve özgüllükleri oldukça değişken olup tanı konulacak tür ya da parazitemi düzeyinden etkilenebilmektedir. DSÖ sıtma tanısında kullanılacak 
uygun bir hızlı tanı testinin; P.falciparum veya P.vivax sıtmasında parazitemi düzeyi 200 parazit/ $\mu$ lan örneklerin en az $\% 75^{\prime}$ ini saptaması, yalancı pozitiflik yüzdesinin \%10'un altında olması ve geçersiz test sonucunun $\% 5^{\prime}$ ten az olması gerektiğini belirtmiştir ${ }^{14}$. Duyarlıı̆ı ve özgüllüğü düşük olan bir hızlı antijen testiyle alınacak sonuçlar tartışmalı olabilir.

Komplike olmayan sıtmada hafif ateş bulunabilir, şuur kaybı görülmez. Hasta oral tedavi alabilir, mortalitesi düşüktür. Şiddetli sıtmada ise, şiddetli anemi tek başına ya da solunum sıkıntısı, metabolik dekompanzasyon ve serebral malarya ile birlikte görülebilir ${ }^{15,16}$. Şiddetli sıtma kliniğinden sorumlu mekanizma parazitle enfekte eritrositlerin mikrovasküler endotele yapışmasıdır. Enfekte eritrositlerin sekestrasyonu sonucu kapillerler tıkanarak organlara giden kan miktarı azalmaya neden olur, konak savunma mekanizmaları sonucu oluşan inflamatuvar hücreler tıkanmayı şiddetlendirir, ayrıca endotel ve kan beyin bariyerine karşı fiziksel hasar gelişir ${ }^{15,17-19}$. Şiddetli sıtma için risk faktörlerinin araştırıldığı bir çalışmada, tedavideki gecikmenin önemli bir risk faktörü olduğu ortaya konmuştur. Hastanın klinik tablosuna koma (\%54.7), akut böbrek hasarı (\%45.3) ve asidik solunumun (\%35.9) eşlik ettiği bildirilmiştir ${ }^{20}$.

Her iki olgu da hastaneye yatırılarak takip edilmiştir. Klinik durumları düzelene kadar yatışları uzatılmış ve parazitemi takibi yapılmıştır. Özellikle ikinci olgunun başvurusu sırasında azalmış solunum sesleri ve dalak büyüklüğü saptanmış, trombositopeni, karaciğer enzimlerinde yükseklik tespit edilmiştir. Hasta şiddetli sıtma kliniği nedeniyle iç hastalıkları yoğun bakım ünitesine yatırımış, takibinde uzun süren oksijen ihtiyacı, hematüri ve kısa süreli bilinç değişiklikleri olmuştur. Özellikle parazitin her yaştan eritrositi enfekte etmesi, enfekte eritrositlerin organ hasarına yol açabilmesi ve yüksek parazitemi seviyeleri nedenleriyle falciparuma bağlı sıtmada hastanın kliniğinde ani bozulmalar görülebilir. Bu yüzden hastaların hastaneye yatııılarak takip edilmesi büyük önem taşımaktadır.

Ok ve arkadaşları ${ }^{21} 22$ yıl öncesine ait yurt dışına çıkmamış, ailesi Urfa'dan Manisa'ya yerleşmiş bir bebek olguya ait ince yayma preparatından DNA izolasyonu yaparak multipleks polimeraz zincir reaksiyonu (PCR) uygulamışlardır ${ }^{21}$. PCR ile hasta kanında hem P.vivax hem de P.falciparum'a ait DNA saptanmıştır ${ }^{21}$. 1996'da saptanan ve 22 yıl sonra moleküler olarak doğrulanan bu olgu, Türkiye'nin iklim ve vektör açısından falciparum sıtması için uygun koşullara sahip olduğunu göstermektedir.

Endemik bölgeye yapılan seyahatlerde uygun profilaksi kullanımı önemlidir. Uzun süren veya sık yapılan seyahatler hastanın profilaktik ilaca uyumunu azaltmaktadır. Koruyucu aşı çalışmaları halen devam etmektedir. Seyahat sonrası kliniğe ateş ile başvuran hastaların ayırıcı tanısında sıtma mutlaka akla getirilmelidir. Tanıda gecikme şiddetli sıtma kliniğiyle sonuçlanarak ciddi morbidite ve mortaliteye neden olabilir.

\section{ÇIKAR ÇATIŞMASI}

Yazarlar bu makale ile ilgili herhangi bir çıkar çatışması bildirmemişlerdir. 


\section{KAYNAKLAR}

1. World Health Organization. World malaria report 2018.

2. Türkiye Cumhuriyeti Sağlık Bakanlığı Sağlık İstatistikleri Yıllığı 2017. Dr. Berrak Bora Başar, İrem Soytutan Çağlar, Asiye Aygün, Tuğcan Adem Özdemir, Sağlık Bilgi Sistemleri Genel Müdürlüğü, Sağlık Bakanlığı, Ankara, 2018.

3. Ozbilgin A, Cavus I, Yildirim A, Gunduz C. The first monkey malaria in Turkey: a case of Plasmodium knowlesi. Mikrobiyol Bul 2016;50(3):484-90.

4. Inkaya AC, Kaya F, Yildiz I, Uzun O, Erguven S. Plasmodium falciparum malaria: evaluation of three imported cases. Mikrobiyol Bul 2016;50(2):328-32.

5. Tunger O, Cakmak A, Ozbilgin A, Tunali V, Cetin CB. Imported malaria in Turkey: the importance of diagnosis and treatment of Plasmodium falciparum/Plasmodium vivax mixed infection. Turkiye Parazitol Derg 2018;42(2):164-7.

6. Ozbilgin A, Topluoglu S, Es S, Islek E, Mollahaliloglu S, Erkoc Y. Malaria in Turkey: successful control and strategies for achieving elimination. Acta Trop 2011;120(1-2):15-23.

7. Eliminating malaria: case study 5. The long road to malaria elimination in Turkey. World Health Organization 2013.

8. Eskiocak M, Karababa AO, Ceylan A, Saka G, Çiçek M. Mardin-Savur ilçesi sıtma salgınını inceleme ve değerlendirme raporu. 2012, Türk Tabipler Birliği Yayınları, Ankara.

9. Sagmak Tartar A, Akbulut A. Epidemiological, clinical, and laboratory evaluation of Plasmodium falciparum malaria cases followed in Firat University hospital: a 6-year retrospective analysis. Turkiye Parazitol Derg 2018;42(1):1-5.

10. Zorbozan O, Pullukcu H, Atalay Sahar E, Karakavuk M, Can H, Tunali V, et al. The importance of the contribution of rapid test, serological and molecular methods in the diagnosis of two imported malaria cases with atypical microscopy. Mikrobiyol Bul 2017;51(4):396-403.

11. Sumer S, Ural G, Ural O. Plasmodium falciparum and Salmonella Typhi co-infection: a case report. Mikrobiyol Bul 2014;48(1):174-8.

12. Centers for Disease Control and Prevention. Malaria information and prophylaxis, by country. Centers for Disease Control and Prevention 2018.

13. World Health Organization. Guidelines for the treatment of malaria. Third edition. World Health Organization 2015.

14. Malaria rapid diagnostic test performance: results of WHO product testing of malaria RDTs: round 7 (20152016). Geneva: World Health Organization; 2017.

15. Cunnington AJ, Riley EM, Walther M. Stuck in a rut? Reconsidering the role of parasite sequestration in severe malaria syndromes. Trends Parasitol 2013;29(12):585-92.

16. Mackintosh $\mathrm{CL}$, Beeson JG, Marsh K. Clinical features and pathogenesis of severe malaria. Trends Parasitol 2004;20(12):597-603.

17. Dondorp AM, Kager PA, Vreeken J, White NJ. Abnormal blood flow and red blood cell deformability in severe malaria. Parasitol Today 2000;16(6):228-32.

18. Clark IA, Alleva LM. Is human malarial coma caused, or merely deepened, by sequestration? Trends Parasitol 2009;25(7):314-8.

19. Medana IM, Turner GD. Plasmodium falciparum and the blood-brain barrier--contacts and consequences. J Infect Dis 2007;195(7):921-3.

20. Zhang T, Xu X, Jiang J, Yu C, Tian C, Xie Q, et al. Risk factors of severe imported malaria in Anhui province, China. Acta Trop 2019;197:104934.

21. Ok UZ, Cavus I, Sidal U, Limoncu E, Özbilgin A. Manisa'da 22 Yıl Sonra Moleküler Olarak Kanıtlanmış Yerli Plasmodium falciparum ve Plasmodium vivax Karma Enfeksiyonu. Mikrobiyol Bul 2019;53(2):239-44. 